\title{
RESPONSE
}

\section{A Jewish Response to "Theological Questions and Perspectives in Jewish-Catholic Dialogue" by Cardinal Kurt Koch}

\author{
Eugene Korn, Center for Jewish-Christian \\ Understanding and Cooperation (Israel)
}

A Response to Cardinal Kurt Koch's October 30, 2011 Keynote Address at Seton Hall University during the $10^{\text {th }}$ Annual Meeting of the Council of Centers on Christian-Jewish Relations

I want to thank the editors of Studies in Christian-Jewish Relations for giving me the opportunity to study and to respond to Cardinal Koch's recent address given at the $10^{\text {th }}$ Annual Meeting of the Council of Centers on Christian-Jewish Relations, particularly since I was unable to attend the meeting and hear the presentation at that time.

I am neither a historian, nor son of a historian. Hence, I should not comment on the historical claims (e.g., the nature of "the primal rift," the extent to which the Shoah can(not) be traced to Christianity, the degree of Christian resistance to the Nazi Final Solution.) As a rabbi and philosopher I am most interested in the theological issues of the unity and differences between our faiths, the relation of Christian Scriptures to Shared Scriptures, the conceptions of salvation, mission and monotheism, and the idea of reconciliation that Cardinal Koch has raised. How much agreement can we attain over these essential religious concepts? What are the implications for Catholic-Jewish relations in the areas of theology and practical cooperation? What are their roles in proper Catholic-Jewish dialogue? And perhaps most importantly, how can we ensure that our "shared patrimony" blossoms into a "shared future"?

These issues have been at the core of the often hostile Catholic-Jewish rivalry throughout our troubled history. Yet one of the truly wonderful signs of the new-found Catholic-Jewish friendship (in Cardinal Koch's words, "the fundamental new beginning") is the degree to which the tone and substance of Cardinal Koch's address is free of polemics or contention when treating these core subjects. To be sure, tensions remain between Jewish and Catholic positions on these issues, but I suspect at least some of them have their source in semantics-particularly regarding "reconciliation"-and even where substantive I sense a palpable ambience of cooperation and empathy in Cardinal Koch's stance toward the Jewish people and Judaism. For this, we should all be grateful.

\section{Unity and Difference}

We should pay close attention to Cardinal Koch's words regarding the uniqueness of ChristianJewish relationship in the context of general inter-religious dialogue. I have frequently been challenged to add Muslims (and Islam) to this dialogue. Certainly Christian-Muslim and JewishMuslim understanding is critical for the future of our ever-shrinking world in which willy-nilly we 
are increasingly thrown together, but to do so would only dilute the distinctive Jewish-Catholic relationship and obscure the unique issues that we must work out together.

Yet a problem—both theoretical and practical—rears its head in Cardinal Koch's accurate formulation of our relationship. Judaism is 'intrinsic' to Christianity but Christianity holds no such essential relationship to Judaism. Most Jews believe that they can come to a coherent theological understanding of Judaism without encountering Christianity at all. Hence, there is a greater need to supply reasons to Jews for pursuing a rich Jewish-Christian encounter than there is for knowledgeable and theologically sophisticated Christians. And practically, the wounds of past Christian-based antisemitism are still open for many Jews. Thus, whereas our joint encounter is urgent for Christians, it seems not so for Jews.

Yet, as Cardinal Koch correctly implies, faithful Jews and Christians now stand together on the defensive as cultural and sometimes demographic minorities. We face the same powerful ideologies, foes and political forces that seek to defeat us, both physically and spiritually. This too makes our contemporary relationship even more distinctive and should naturally provide impetus to greater dialogue and cooperation between us.

Cardinal Koch reiterates Pope Benedict's call for Jewish and Christian understandings of Holy Scriptures to enter into dialogue with one another. This is surely a fruitful and as yet largely untapped agenda for future dialogue. Yet aside from the benefits of pure scholarship and the blessings earned from learning more deeply about each other, we need to think carefully about what this dialogue around the Bible would look like and toward what ends it would be best directed. Here we encounter another fundamental asymmetry: Christians can and should approach Jewish Scriptures as holy and possessing divine dimension, yet Jews need notindeed cannot if they are to be faithful to rabbinic tradition-ascribe the same theological characteristics to exclusively Christian Scriptures. Thus it would seem that if this joint biblical dialogue is not to lapse into mere academic scholarship and proceed as a religious enterprise, it would need to be limited to Shared Scriptures. Is this indeed what Rome intends?

Catholics and Jews should spend more time plumbing the meaning of the claim that "the Jewish reading of the Bible is a possible one." If this Jewish reading that is void of any Christology or Christian doctrine is possibly correct, how can a Christian not see it as separate from the good news of Christian Scriptures-i.e., Marcionism or some form of supersessionism? Is it possible for the Jewish reading to be (objectively) correct for Jews but of necessity objectively incorrect for faithful Christians? This is the kind of relativism that for good reason the Church usually rejects. On the level of mutual recognition and good relations, this idea is welcome, but it is not apparent to me that it can be made to be theologically coherent. I do not have any definitive answers to these conundrums, but they seem to me to be worthy of systematic pursuit by Jews and Christians, both together and by themselves.

\section{Covenant}

Perhaps, then, the joint understanding of the Jewish and Christian Scriptures as literature prefigures some doctrinal and theological issues that Jews and Christians must confront if they are to understand God's Covenant as the foundation of their religious lives and their relationship with The Holy One.

Most Jews have difficulty sharing their covenantal history with Christians. This is true both for historical reasons (vying for the same covenantal love led frequently to a harsh and sometimes violent sibling rivalry) and for theological reasons. For Jews, covenantal history reached its 
definitive pre-eschaton apex with revelation at Sinai and the Mosaic commandments. If so, it is difficult to see Christianity as a continuation of that same covenantal history and Christians as partners in that covenant without entailing some form of supersession or cancellation of the Torah of Moses. Indeed, as Pope Benedict has observed in this context, the Sinai covenant has been superseded. ${ }^{1}$ Christians do not understand themselves as obligated in the observance of all the Sinaitic commandments. For example, the Sinaitic Decalogue prohibits making any physical likeness or image of God and requires the observance of the Sabbath on the seventh-not the first-day of the week, two commandments that Christianity does not acknowledge as binding and that Christians do not observe. In sum, I see no way for Christians to stand together with Jews at Sinai.

I do applaud Cardinal Koch's insistence that Jews and Christians are both included in the Abrahamic covenant reaching back to the very origins of Jewish history and Judaism, and that were Christians to lose their identification with that covenant, they would also lose their historical legacy and spiritual moorings. To be sure, Christianity has been greatly successful in fulfilling God's universal charge to Abraham to bring the knowledge of God and his morality to the world: "Through you all the nations of the earth shall be blessed." ${ }^{2}$ If the Jewish people remain particular and limited through their fidelity to the Sinaitic covenant, the Church has promoted this Abrahamic covenantal telos by spreading God's word and moral law to the nations. ${ }^{3}$ And here the Church serves a vital function to Israel, reminding us that our commitment to the particularist Mosaic legislation must never be allowed to eclipse the universal covenantal vision that God had for all of Abraham's children. Now that Christianity is no longer a threat to Jews and Judaism, Jews must admit that covenantally, both Jews and faithful Christians are children of Abraham. How Jews and Christians can share Abraham's covenant, and yet preserve our differentiated roles in divine history so that our continuing distinctive identities are enriched and not threatened, is no trivial challenge. This seems to me to be an essential task for our dialogue. ${ }^{4}$

I also deeply appreciate Cardinal Koch's insistence that Jewish people as the people of God is an ethnological fact in God's plan, not only a theological community. This point has been often missed on Christian thinkers who insist on seeing Israel in terms similar to the Church-a faith community rather than a people. Biblically and historically, Jews are a people with both national and cultural characteristics that are essential to our identity and which carry with them the rights and protections accorded to all nations and peoples. It is the people of Israel and its permanent endurance in history that provides powerful witness to God's existence and promise. Pope Benedict recognized this theological significance of Jewish existence when he boldly proclaimed during his visit to Auschwitz in 2006: "If this people, by its very existence, was a witness to the God who spoke to humanity and took us to himself, then that God finally had to die and power had to belong to man alone-to those men [Nazis], who thought that by force they had made themselves masters of the world."

\footnotetext{
${ }^{1}$ Josef Ratzinger (now Pope Benedict XVI) asserted the supersession of the Sinai covenant in the very same passage in which he insists on Christian participation in that covenant. Many Religions One Covenant (San Francisco, 1999) pp. 70-71.

${ }^{2}$ Gn 12:3

3 This point was acknowledged by the traditionalist rabbinic authorities Maimonides (12 ${ }^{\text {th }}$ century) Mishneh Torah, Laws of Kings 12:1, Jacob Emden (18 ${ }^{\text {th }}$ century) Seder Olam Rabbah 35-37, Sefer ha-Shimush 15-17, and Commentary on Ethics of the Fathers 4:11, and Samson Raphael Hirsch, Principles of Education, "Talmudic Judaism and Society," 225-227, and Nineteen Letters on Judaism, edited and annotated by Joseph Elias (Jerusalem, 1995).

${ }^{4}$ For additional reflections on sharing the Abrahamic covenant, see my "Covenantal Possibilities in a Post-Polemical Age" in Studies in Christian-Jewish Relations Vol. 6 (2011) found at http://ejournals.bc.edu/ojs/index.php/scjr.
} 
Important corollaries flow from this recognition. If as both Pope Benedict and Cardinal Koch insist, the existence of the Jewish people today is no mere political or empirical datum but one that is pregnant with theological significance constituting witness to God, to His covenant and to sacred history, then protecting the existence and security of the Jewish people must be a religious obligation-both for Jews and the Church. And this practical obligation is most urgent today in light of Cardinal Koch's observation that "the scourge of anti-Semitism seems to be ineradicable in today's world."

In our time, the State of Israel is the home, indeed the body of the Jewish people. It is also the best guarantor of Jewish survival. If post-Holocaust Jews have any rational grounds for believing in the survival of the Jewish people and that our future is not as precarious as our past, it is only because of the strength of the Jewish State to protect them and the friendship of the Church and the more than two billion Christians around the world.

Yet the most virulent and acceptable form of antisemitism is anti-Zionism. Here I refer not merely to opposition to particular Israeli policies, but to the denial of the right of the Jewish people to their own country, and the aggressive public threats to destroy it politically and militarily. This virulent anti-Zionism can be found in extreme leftist political circles, most Muslim countries, Palestinian Liberation Theology, some groups within mainline Protestant churches and it is now making headway even within the Catholic Church. While in the past destroying the Jewish people took the forms of anti-Judaism and racial extermination, today it takes the form of attempts to destroy the Jewish State and its citizens. If the continued existence of the Jewish people is truly testimony to God's promise and His faithfulness that the Church holds dear, if it is "the taproot of the Christian faith," then it would seem that forcefully and unequivocally supporting the State of Israel-but not necessarily all its policies-from its existential enemies is a religious obligation devolving upon the Church. This is not a contingent political issue, but a theological necessity. ${ }^{5}$ Sensitive to the Church's political interests as well as to its responsibility for Christians in the Middle East, supporting Israel's security and existence must be done carefully. However there seems no theological justification for neutrality or diplomatic silence regarding defending Israelboth the people and the state-before the world. Aside from the implications for Church policy, the theological significance of the Jewish people's return to their covenantal homeland should be a topic for Jewish-Catholic religious dialogue.

The idea of reconciliation, so important in Catholic discussions of contemporary Catholic-Jewish relations and so prominent in Cardinal Koch's address, requires fuller exploration and explication. Is it primarily the historical reconciliation of old enemies? The moral reconciliation of resolving the claims of each upon the other? The theological reconciliation of our differences and beliefs? If so, to what extent? Or the existential reconciliation of two disparate communities that will take place in the distant eschaton? What meaning do Jews and Christians give to each of these ideas and are they indeed desirable or perhaps threatening?

Cardinal Koch stresses that salvation for Jews need not entail conversion to Christianity, that Jewish witness is still vital to Christian faith, and that "unification with the Church may occur at a determined point in time which cannot be anticipated." ${ }^{6}$ This I hope reinforces the recent USCCB

\footnotetext{
${ }^{5}$ At a November 2011 meeting in New York between Cardinal Koch and Jewish leaders, I was shocked to hear a Vatican representative in the Cardinal's delegation imply that a vigorous Vatican defence of Israel would be a quid pro quo for Israeli flexibility in negotiations regarding Israel-Vatican accords. This exclusively political conception of the relationship was theologically wrong-headed, as well as deeply disturbing to Jewish leaders.

${ }^{6}$ I take this to mean not in our time but in the distant eschaton, as put by Cardinal Ratzinger "theological unification is hardly possible within our historical time and perhaps not even desirable." Many Religions One Covenant, p. 109.
} 
clarification that efforts at conversion per se have no place in Catholic-Jewish dialogue. ${ }^{7}$ If so, I see no reason whatsoever why any Jewish person should object to the Church's insistence in the universal salvific significance of Jesus. If the universal significance of Jesus is freed from any connotation of conversionary mission "to" the $\mathrm{Jews}^{8}$, this theological point seems a strictly internal matter of Catholic doctrine. Of course, it is acutely interesting for students of rational theology and logic to observe how Catholic thinkers approach the paradox of Jesus' universal significance and the enduring legitimacy of Judaism and Jews who continue to deny Jesus' divinity and salvific character. Is this divine paradox a vicious inconsistency to be eliminated or a virtuous mystery that is cause for humble reflection and celebration $?^{9}$ Perhaps the Catholic approach to this mystery can guide Jews in dealing with some of our own dilemmas, such as how we can be God's singular chosen people and yet see gentiles also as God's people.

Nor should there be any problem with dialogue taking up the difference between the Christian belief in the Trinity and the Jewish denial of it, as long as such discussion avoids the metaphysical question of the ultimate truth of God's nature (absolutely one or trinitarian). The rabbis long ago made peace with the legitimacy of Christians believing in a trinitarian God while prohibiting that belief to Jews, who are required to believe in an absolutely monotheistic God. ${ }^{10}$ From the point of view of Jewish theology and our task together, what is crucial is that we both believe in the one Creator of heaven and earth who is in covenantal relation with us. On this point, Cardinal Koch does us a great service by advancing the promising idea that the best meaning of the Trinity to be taken up for development in Catholic-Jewish dialogue is "God's devotion to the world initiated already in creation and continued salvation history, so that God lives in a relational unity with his people."

This is a wonderful fertile path for dialogue to follow. If we take up Cardinal Koch's call and focus both on the practical meaning of God's devotion to the world through his relatedness to covenanted peoples, we return to Jews and Christians being partners in the covenant of Abraham and functioning as God's witnesses.

How shall we live the covenant of Abraham and by testifying as he did? If we are true to the biblical account of Abraham, we must admit that the Bible does not portray Abraham as a theologian, but as a man of faith, action, and morality. His covenant, then, should above all entail

\footnotetext{
${ }^{7}$ See USCCB Statement of Principles for Catholic-Jewish Dialogue, October 2, 2009 found at http:/www.usccb.org/sia/StatementofPrinciples.pdf, accessed on February 26, 2012.

${ }^{8}$ I urge caution and the need for clarification on this point. Cardinal Koch quotes Walter Kasper as stating that "the mission command is just as valid for Jews as for the other nations, but it must be realized differently for the Jews." The details of just how mission is different for Jews needs to be explicated, and here the details make all the difference for our relationship. Perhaps-but not necessarily-Kasper's earlier statement on mission is of help here: There is "no mission to the Jews," either in dialogue or outside of it. There is only "mission with the Jews." There is dialogue with Jews; no mission in the proper sense." (Paper delivered at the $17^{\text {th }}$ meeting of the International Catholic-Jewish Liaison Committee, New York, NY, May 1, 2001, 3, published in America Magazine, Vol. 195, no. 7, September 17, 2001 and www.bc.edu/research/cjl/jcrelations/resources/articles/\#dominusiesus.)

${ }^{9}$ See Richard Sklba, "New Beginnings: Catholic-Jewish Relations After 40 Years," Origins 35, no. 31 (January 19, 2006): 509-514, who argues that the tension between the universal theological claim of Christianity and the enduring particular validity of the Jewish covenant is a mystery to be appreciated.

10 Tosefot, B.T. Sanhedrin 63b, s.v. Assur. See my Rethinking Christianity: Rabbinic Positions and Possibilities, (Littman Library of Jewish Civilization, 2012) pp. 189-215, particularly pp. 197-199.
} 
a commitment to effective moral testimony and to practical action in sacred history. Covenantal Jews and Christians, therefore, must heed God's call to bring blessing to the world. When we do this we play an essential role in sacred God's plan for human history-indeed for the survival of humanity. We do this together by publicly bearing witness to God's covenantal values. And it is precisely today, after the Holocaust and in the midst of cultural forces dominated by materialism, relativism, and extremism that the practical values of Abraham's covenant assume particular urgency. Neither Catholics nor Jews-nor, I believe, humanity-can flourish when these cultural forces dominate human life.

Following the model of covenanted Abraham, defending divine moral values needs to be foremost in our behaviour and theology. ${ }^{11}$ Simply put, there is no justification for any teleological suspension of the ethical-whether the telos be theological, political, financial, or personal. And general theological agreement on this point does not suffice. Both God and human experience are in the details. We need specific testimony and I suggest the following:

1. There is a spiritual center to the universe because the world was created by a loving God, who is intimately involved in human lives and who yearns to redeem His children. Jews and Christians should be unembarrassed about teaching this reality, as was Abraham who made God known as the "God of Heaven and Earth."

2. As Creator, God is the transcendent authority over human life and who establishes the validity of moral values. Although sometimes difficult to apply, moral values are neither relative nor human conventions, but intrinsic parts of the universe that are essential for human flourishing. The fundamental moral values must remain primary to all human endeavors.

3. All persons are created in the Image of God, and each person has intrinsic sanctity deriving from this transcendent quality. All persons therefore possess inherent dignity and much be treated as such. Because human life has this spiritual character, human worth cannot be measured solely in utilitarian or materialistic terms. The divine essence of each person ensures that individual human life is not a process of biological decay toward death but a journey of spiritual growth toward life. And because every person is created in the Divine Image, any assault on innocent human life is an assault on God that diminishes the Divine Presence in the world.

4. Abraham learned from the binding of Isaac that God loves human life and abhors death. Thus, Abraham's covenanted children must teach that killing in the name of God is contrary to the God of Abraham, and all forms of irrational religious extremism and religious violence ${ }^{12}$ are false idolatries that the world must reject.

5. As Abraham defended and taught justice and righteousness before the destruction of Sodom and Gomorrah, his children are duty bound to teach social justice and display individual righteousness. It was Abraham's moral protest to God and concern for the moral treatment of others that distinguished his righteousness from the self-righteousness of Noah, and that earned him the privilege to be the father of the covenant. Our commitment to justice and righteousness for

\footnotetext{
${ }^{11}$ In the Bible (Gn 18:17-19) as well as Jewish theology, Abraham merited being father of the covenant because he demonstrated that "he would instruct his children and his posterity to keep the way of the Lord by doing righteousness and justice."

${ }^{12}$ I exclude from this category capital punishment, which draws its justification from biblical and theological sources according to many religious theories of legal justice, as well as actions in self-defense against verifiable and imminent physical threats.
} 
all human creatures is the test of our fidelity to God's covenant that is designed to bring blessing to the world.

6. As faithful Christians and Jews believing in messianic history, we must teach the eternal possibility of human progress and moral reform as part of human history. We cannot fall prey to pessimism, nihilism, cynicism masquerading as "political realism," or a Malthusian acceptance of war, disease, and oppression as permanent features of human destiny. Hope in possibility of a peaceful humanity is the meaning of our messianic belief.

Although critical theological differences exist between us, both Jews and Christians believe that God yearns to enter the world and that human history will culminate in messianic redemption. Our task today is to make the world a better place through teaching and witness, to create a place where God can enter. But neither faith can do this in isolation from our covenantal partner. Overcoming our adversarial past is a slow and painful task. Will we have the courage and wisdom to do so?

The ground for this holy task has been broken by our leaders in the past 60 years, and we must continue to till this still tender vineyard. Our covenantal Father demands nothing less from us. 